\title{
Women Development And Government Schemes With Special Reference To Ksy
}

\author{
Dr. Tanusree Sarker \\ Department of Political Science, Women's College, Tinsukia University of Dibrugarh India
}

\begin{abstract}
Women are the most vulnerable group in a major parts of India. India's North Eastern region is quite backward comparing to other parts of the country and the condition of women is also not so good. Adolescence is a stage when a girl sees a number of changes in her physical and mental health. In this stage she needs proper nutrition for her all round growth. But in our country specially in this part of the country the girls face lot of obstacles including mal nutrition due to which she lacks proper growth of her body and mind. The Government of India thus introduced a number of schemes for the welfare of the people and more specifically for the women and girls. But the schemes also do not reach to the appropriate group of people because of lack of awareness and corruption along with a number of other reasons. In this paper a modest attempt has been made to analyse the causes of poor performance of the Govt. schemes on the basis of available data collected from different sources and Govt. data and produces a comparative chart of the implementation of the Govt. schemes in the eight North Eastern states of India. The study has given special emphasis on KSY(Kishori Shakti Yojona), an important scheme for the development of adolescent girls and its implementation in different states of North East India.
\end{abstract}

Key Words: Adolescence, Govt. schemes, Human Development Index, KSY, Mal nutrition, UNDP

"The basic purpose of development is to enlarge people's choices. In principle, these choices can be infinite and can change over time. People often value achievements that do not show up at all, or not immediately, in income or growth figures: greater access to knowledge, better nutrition and health services, more secure livelihoods, security against crime and physical violence, satisfying leisure hours, political and cultural freedoms and sense of participation in community activities. The objective of development is to create an enabling environment for people to enjoy long, healthy and creative lives." Mahbub Ul Haq, the founder of human development report.

\section{Introduction}

Human development is a development paradigm that is about much more than the rise and fall of national incomes. The objective of human development is to create an environment in which people can develop their full potential and lead productive and creative lives as per their needs and interests. The real wealth of a nation is the people and more specifically the men, women and children of a nation. Thus, human development means the development of the nation as a whole. Development expands the choices that people have to lead lives and they value. The most basic capabilities for human development is to lead a long and healthy lives, to access to the resources needed to lead a descent standard of living, to acquire knowledge and to be able to participate in the social and political activities.(1).

Women occupy nearly half of the world population but women in every parts of the world lack support for fundamental functions of human life. They are less well nourished than men, less healthy, more vulnerable to physical violence and social abuse. They do not get adequate opportunities for education and career development. They face lot of obstacles in work place, and to participate in political life effectively.(2). The unequal social and political circumstances give women unequal human capabilities. The purpose of human development is to expand human capabilities and human include both man and woman. Hence, it is necessary to create such environment that enlarges the choices of each child to be a perfect human being who can lead a creative decent standard of living in future. The UNDP has introduced the gender related development index since 1995. The report takes into account the inequality in achievement between men and women. Infact, empowered women can contribute to human development through household and community activity and at the same time progress in human development is expected to promote women empowerment through improved health, nutrition, education, social security, political freedom, availability of employment and decent standard of living.(3) The gender empowerment measure focuses on gender inequality in three areas as political participation and decision making power, economic participation and decision making power and power over economic resources. As such, the nation as whole struggling to fulfill the agenda of women empowerment. 
Gender disparity in all the NE states have been quite miserable. Nagaland has been emerged as the worst performer and Meghalaya the second worst position in the country in empowerment measure. Mizoram and Manipur though better performer in HDI but lagging behind in empowering women in their respective states. Assam ranked 26, out of 35 states and UTs and the promotion of 17 points by Arunachal Pradesh was possible mainly due to the encouraging growth in the index value of economic participation and decision making power during the decade has kept the hope alive for the entire region.(4). In order to reduce the volume of gender inequality which has created mainly due to poverty and social hindrances the Government of India has introduced a number of schemes for the progress and development of poor families including women.

In our country, the girl children are much neglected from the very beginning and as a result they are still lagging behind in most of the aspects than men. Assam and other North Eastern states are not exception in this reality. Hence, I will be discussing here an important Government scheme which, if implement properly, the girl child of our country may be developed physically, mentally and educationally. The scheme is popularly known as KISHORI SHAKTI YOJANA for adolescent girls. Adolescence is a crucial stage in the life of every girl. At this stage she stands at the threshold of adulthood. This stage is intermediary between childhood and womanhood and it is the most eventful for mental emotional and psychological well-being. The life cycle approach for holistic child development remains unaddressed if adolescent girls are excluded from the developmental programs aimed at human resource development.(5)

\section{Objective of the paper}

Kishori Shakti Yojana(KSY) earlier known as National Programme for Adolscent Girls is implemented as a component of ICDS schemes in limited number of ICDS projects and KSY has been implemented from 2011 as a part of SABALA scheme. Various survey in different parts of the country reveal that the adolescent girls $\mathrm{d}$ not have adequate access to vital health and nutrition. Thus, this paper makes a modest attempt to analyse the role of KSY for women development in the North Eastern States.

\section{Methodology}

A statistical-analytical method has been followed on the basis of available data from various sources including Government documents, journals, books and websites to discuss the issue here.

\section{List of Government schemes for women development}

For empowerment of women and all round development of women the Ministries of Government of India has come up with various schemes time to time. These schemes are either central, state specific or joint collaboration between the centre and states. Some of the schemes, time of launching and provisions of these schemes are mentioned here in the following table:

Table-I: Source: http://en.wikipedia.org/wiki/ministry_of human_resource development_india

\begin{tabular}{|c|c|c|c|}
\hline Scheme & Ministry & Launched on & Provisions \\
\hline $\begin{array}{l}\text { Indira Gandhi Matritva Sahyog } \\
\text { Yojana }\end{array}$ & MoWCD & 2010 & $\begin{array}{l}\text { A cash of Rs. } 4000 /- \text { to women (above } 19 \text { yrs) for } \\
\text { the first two live births }\end{array}$ \\
\hline $\begin{array}{l}\text { Integrated child development } \\
\text { services }\end{array}$ & MoWCD & October 2, 1975 & $\begin{array}{l}\text { Tackle malnutrition and health problems for both } \\
\text { mother and children (below } 6 \text { yrs). }\end{array}$ \\
\hline Janani Suraksha Yojana & MoHFW & 2005 & $\begin{array}{l}\text { One time cash incentive to pregnant women for } \\
\text { institutional /home births through skilled } \\
\text { assistance }\end{array}$ \\
\hline $\begin{array}{lll}\text { Kasturba } & \text { Gandhi } & \text { Balika } \\
\text { Vidyalaya } & & \\
\end{array}$ & MoHRD & July 2004 & $\begin{array}{l}\text { Educational facilities for girls(residential schools) } \\
\text { belonging to SC,ST,OBC,minority communities } \\
\text { and BPL in educationally backward blocks }\end{array}$ \\
\hline $\begin{array}{lll}\text { National } & \text { Literacy } & \text { Mission } \\
\text { Programme } & & \\
\end{array}$ & MoHRD & May 5,1988 & $\begin{array}{l}\text { Make } 80 \text { million adults in the age group of } 15 \text { - } \\
\text { 35(both sex) literate }\end{array}$ \\
\hline $\begin{array}{lll}\begin{array}{l}\text { National } \\
\text { scheme }\end{array} & \text { Social Assistance } \\
\end{array}$ & MoRD & August 15, 1995 & $\begin{array}{l}\text { Public assistance to its citizens in case of } \\
\text { unemployment, old age, sickness and disablement }\end{array}$ \\
\hline $\begin{array}{l}\text { SABALA or Rajiv Gandhi } \\
\text { scheme for empowerment of } \\
\text { adolescent girls }\end{array}$ & MWCD & March 8, 2011 & $\begin{array}{l}\text { Empowerment of adolescent girls } 11-18 \text { yrs with } \\
\text { focus on out of school girls by improvement in } \\
\text { their nutritional and health status and upgrading } \\
\text { home skills, vocational skills and life skills } \\
\text { merging NPAG and KSY schemes. }\end{array}$ \\
\hline $\begin{array}{l}\text { Swarnajayanti Gram Swarozgar } \\
\text { Yojana }\end{array}$ & MoRD & April 1, 1999 & $\begin{array}{l}\text { Bring the assisted poor families above the } \\
\text { poverty line by organizing them into SHGs } \\
\text { through the process of social mobilization, their } \\
\text { training and capacity building and provisions of } \\
\text { income generating assets through a mix of bank } \\
\text { credit and government subsidy }\end{array}$ \\
\hline Swavalamban & $\mathrm{MoF}$ & $\begin{array}{l}\text { September } \\
2010\end{array}$ & $\begin{array}{l}\text { Pension scheme to the workers in unorganised } \\
\text { sectors. }\end{array}$ \\
\hline
\end{tabular}




\begin{tabular}{|l|l|l|l|}
\hline Swabhiman & MoF & February 15,2011 & $\begin{array}{l}\text { To make banking facility available to all citizens } \\
\text { (both male and female) }\end{array}$ \\
\hline Udisha & MoWCD & $1999-2000$ & $\begin{array}{l}\text { Nationwide training component of the world } \\
\text { bank assisted women and child development } \\
\text { project. }\end{array}$ \\
\hline
\end{tabular}

\section{Kishori Shakti Yojana(KSY)}

Kishori Shakti Yojana(KSY) earlier known as National Programme for Adolescent girls(NPAG) is implemented as a component of ICDS(integrated child development services)in limited number of ICDS projects. From 2006-07 the Govt. of India issued instruction for expansion of the schemes to all ICDS projects and accordingly released funds during the end of the financial year 2006-07. But due to the technical problem in the Finance Dept. the scheme KSY could not be implemented during 2006-07 session.(6). Hence, the scheme was implemented during 2007-08 session and as per the budget also allocated. Later on the scheme KSY was merged with Sabala or Rajiv Gandhi scheme for empowerment of adolescent girls from March 8, 2011. The objective of KSY is to improve the nutritional, health and development skills of adolescent girls, promote awareness of health, hygiene, nutrition and family care and link them to opportunities for learning life skills, going back to schools, help them gain a better understanding of the social environment and take initiative to become productive members of the society.(7).There are two phases of KSY. In phase I, CDPO and DPOs will be subjected to three days training and orientation to prepare them to act as master trainers to impart training to adolescent girls in their respective projects. A team of professional experts train them in eight different courses. These are:

$>$ Adolescent Health- This course covers pre-adolescent youths, family life education for youth, adolescent sexuality and stages of development topics.

$>$ Adolescent Biology-The topic of this course are physical changes, health and nutrition.

$>$ Marriage-The topic covers in this course is responsible parenthood.

$>$ Communication skill-The course content of this component is communication skill within the family.

$>$ Adolescent and Stress- It trains to cope with stress and emotions, intelligence among adolescent.

$>$ Developing skill-This course covers self awareness, decision making and inter-personal.

$>$ Protecting adolescent from high risk situations as alcohol/drugs/STI/HIV\& AIDS.

$>$ Legal Rights- Child rights, human trafficking, reproductive rights. This course also covers---

a) Nutritional and health status of girls in the age group of 11-18 years, knowledge to help m improve decision making capabilities.

b) Health, hygiene, nutrition.

c) Family welfare, home management.

d) Taking all means to facilitate their marriage only after attaining the age of $18 \mathrm{yrs}$. and if possible later.

e) Better understanding environment related social issues and its impact on their lives and

f) Encourage adolescent girls to various activities to be productive and useful women to the society $(8)$.

In the II phase of KSY two adolescent girls in each Anganwadi centre will be imparted training for two days on vocational trades, non formal education course, health and nutrition education and legal literacy etc. Training will be imparted to CDPOs and supervisors after they are being master trainers. The Divisional Programme Officer will be overall incharge of the second phase of training programme and shall act as course director. Fund will be placed at the disposal of programme officer of divisional ICDS cell. The implementation machinery of the scheme is the director who controls and supervises implementation through Divisional programme officers, District social welfare officers and child development project officers. The scheme should be monitored by the ICDS Network. In case of Assam, block level vigilance and monitoring committee has been constituted for affective monitoring and implementation of the scheme (Notification no. SWD,245/205/103, dated Dispur, the $8^{\text {th }}$ March, 2007).

\section{Implementation of KSY in North Eastern States of India}

India's North Eastern Region is a conglomeration of eight states-Arunachal Pradesh, Assam, Manipur, Meghalaya, Mizoram, Nagaland, Sikkim and Tripura with nearly $8 \%$ of national area the region as a whole offers home to less than $4 \%$ of national population and out of which the state of Assam alone accommodates over $68 \%$ of regional population. The table below shows the no. of Aganwadi centers and coverage of KSY in all the NE states: 
Women Development And Government Schemes With Special Reference To Ksy

\begin{tabular}{|l|l|l|l|l|}
\hline SL NO & State & No of AWC & No of AWC in operation & Coverage of KSY \\
\hline 1. & Arunachal Pradesh & 1751 & 661 & 79 \\
\hline 2. & Assam & 22613 & 7232 & 219 \\
\hline 3. & Manipur & 3889 & 2074 & 34 \\
\hline 4. & Meghalaya & 493 & 460 & 39 \\
\hline 5. & Mizoram & 298 & 176 & 23 \\
\hline 6. & Nagaland & 261 & 207 & 56 \\
\hline 7. & Sikkim & 245 & 103 & 11 \\
\hline 8. & Tripura & 2527 & 653 & 51 \\
\hline
\end{tabular}

Table II: Source: http://wed.nic.in/ksy/ksystatewise.htm

\begin{tabular}{|l|l|l|l|l|}
\hline SL No & State & Fund Released in 2009-10 & Fund Utilized & $\%$ of expenditure \\
\hline 1. & Arunachal Pradesh & 23.1 Lakh & 11.55 Lakh & $50 \%$ \\
\hline 2. & Assam & $68.2 \mathrm{Lakh}$ & $34 \mathrm{Lakh}$ & $49.85 \%$ \\
\hline 3. & Manipur & $15.4 \mathrm{Lakh}$ & 0 & 0.00 \\
\hline 4. & Meghalaya & $35.2 \mathrm{Lakh}$ & $21.25 \mathrm{Lakh}$ & $60.37 \%$ \\
\hline 5. & Mizoram & $23.1 \mathrm{Lakh}$ & $23.1 \mathrm{Lakh}$ & $100 \%$ \\
\hline 6. & Nagaland & 45.1 Lakh & $22.55 \mathrm{Lakh}$ & $50 \%$ \\
\hline 7. & Sikkim & 5.5 Lakh & $2.75 \mathrm{Lakh}$ & $50 \%$ \\
\hline 8. & Tripura & 0 & 0.00 \\
\hline
\end{tabular}

Table III: Source: $\underline{\mathrm{http}: / / w e d . n i c . i n / k s y / k s y e x p . h t m ~}$

The above figures highlight how the scheme is being operationalized in this region. There are total 6118 coverage of KSY in the whole country out of which NE Region covers only 512 which is just $8.3 \%$ of national coverage(9).. Except Mizoram no other states of the region could utilized the whole fund released for the implementation of the scheme. In 2010-11 financial year the total no. of ICDS projects sanctioned for Assam was 228 , out of which only 118 were operationalized in rural areas, 10 in urban areas and 30 in tribal areas. Rest of the projects remained untouched.(10)

\section{Implementation of KSY after merging with Sabala scheme}

Sabala or Rajiv Gandhi scheme for empowerment of adolescent girls was launched on $8^{\text {th }}$ March 2011. The objective of this scheme is to empower adolescent girls of 11-18 yrs with focus on out of school girls by improvement in their nutritional and health status and upgrading various skills like home skills, life skills and vocational skills. This scheme merged with NPAG and KSY.

\begin{tabular}{|l|l|l|l|l|l|}
\hline SL NO & State & No of KSY block & $\begin{array}{l}\text { Amount released } \\
\text { in 2011-12 }\end{array}$ & Spent/unspent & $\begin{array}{l}\text { Amount released } \\
2012-13\end{array}$ \\
\hline 1. & Arunachal Pradesh & 55 & $30.25 \mathrm{Lakh}$ & Spent & 30.25 \\
\hline 2. & Assam & 153 & $84.15 \mathrm{Lakh}$ & $\begin{array}{l}\text { Yet to submit the } \\
\text { report }\end{array}$ & Not applied \\
\hline 3. & Manipur & 22 & $12.1 \mathrm{Lakh}$ &, &, \\
\hline 4. & Meghalaya & 19 & $10.45 \mathrm{Lakh}$ & 0.09 Lakh unspent & $10.38 \mathrm{Lakh}$ \\
\hline 5. & Mizoram & 12 & $6.6 \mathrm{Lakh}$ & Spent & $6.6 \mathrm{Lakh}$ \\
\hline 6. & Nagaland & 40 & $22 \mathrm{Lakh}$ & Yet to submit & Not Applied \\
\hline 7. & Sikkim & 5 & $2.75 \mathrm{Lakh}$ &,$\%$ & , \\
\hline 8. & Tripura & 28 & $15.4 \mathrm{Lakh}$ & 4.92 Lakh unspent & $25.88 \mathrm{Lakh}$ \\
\hline
\end{tabular}

Table-IV: Source: wcd.nic.in/schemes/sabala.htm

From the table it is clear that fund released for each state for proper implementation of KSY but only Arunachal Pradesh and Mizoram utilized whole amount released for the scheme for the financial year 2011-2012 and they received $2^{\text {nd }}$ installment too for the session 2012-13. But rest of the states including Assam yet to submit the expenditure report to the Govt. of India, Ministry of Women and Child development. Thus, they have not yet received the $2^{\text {nd }}$ installment for the financial year 2012-13.

\section{Conclusion}

Human development is a sustainable expansion of human capabilities and for this equal opportunities for all round development of both the sexes is essential. Women of this region though occupy much better position in comparing to other parts of the country but the development of rural women are not at the same footing. Assam comparatively in little higher position than other states of this region. But it is a matter of concern that a large number of rural women are still totally ignorant about the schemes and benefits of the schemes. The scheme KSY is supposed to cover maximum adolescent girls as the target of the Govt. is to cover one crore adolescent girls each year. But a large number of adolescent girls are yet to include in the scheme. Most of the people are unaware of the scheme. Thus, it is necessary to educate the people at the grass root level 
and circulate about the schemes among the people as many as possible. Fund should be utilized properly so that the purpose of the scheme be served. All policies relating to the development of women must reach up to the grass root level. The gender discrimination can be reduced if each girl receives the benefit of KSY. It is a common factor that in our country many Govt. schemes do not reach to the needy people due to large scale corruption. So it is necessary to root out corruption from the society for proper utilization of Govt. fund as well as sincere effort of officers to implement the schemes as per Govt. policies. Steps need to be taken to increase the effectiveness of service delivery the Govt. of all the NE States need to address the issues for making sustainable path of development for their respective states and the region as a whole. For women development, the chief Minister of Assam proposed to reserve upto $20 \%$ of the Government supplies and contracts not exceeding Rs. 10 lakh for women.He also proposed to enhance the exemption limit to $2 \%$ for registration fees of land not exceeding Rs. 2 lakh for women. 50,000 single unemployed women will be provided assistance at the rate of Rs. 10,000/- each. Similarly marriage assistance will be provided to BPL girls at the rate of Rs. 10,000/each and cash assistance of Rs. 5,000/- each to one lakh women self help group has also been proposed. An amount of Rs. 1 crore has been provided to state's women commission as building grant. He also proposed to set up a woman welfare council to look after overall welfare of women(11). If half of these proposals are implemented in the truest sense, we may see Assam in a higher rank in Human Development Index. As Prof. Amartya Sen writes,

"Twenty years after the appearance of the first Human Development Report, there is much to celebrate in what has been achieved. But we also have to be alive to ways of improving the assessment of old adversities and of recognizing-and responding to-new threats that endanger human well being and freedom".

\section{End Notes and References}

[1]. Human Development Reports- United Nations Development Programme

[2]. "Women and Human Development"; Martha C. Nussbarm

[3]. "Women empowerment in Assam: A Human Development Approach"; Bidisha Mahanta.

[4]. "Human Development in North East India", Yojana, Dec. 2010; pp-30-34

[5]. Guidelines of KSY; www.nic.in/ksy

[6]. Department of Social welfare, Govt. of Assam

[7]. Ibid

[8]. Guidelines of KSY

[9]. Ministry of Women and Child Development, Govt. of India

[10]. Department of Social Welfare, Govt. of Assam

[11]. The Assam Tribune, March 16, 2010 